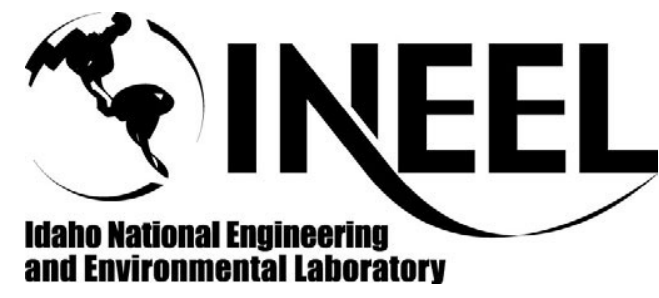

INEEL/CON-01-01633

PREPRINT

Post-Harvest Processing Methods For Reduction Of Silica And Alkali Metals In Wheat Straw

David N. Thompson

Peter G. Shaw

Jeffrey A. Lacey

April 28, 2002

$24^{\text {th }}$ Symposium On Biotechnology For Fuels And Chemicals

This is a preprint of a paper intended for publication in a journal or proceedings. Since changes may be made before publication, this preprint should not be cited or reproduced without permission of the author.

This document was prepared as an account of work sponsored by an agency of the United States Government. Neither the United States Government nor any agency thereof, or any of their employees, makes any warranty, expressed or implied, or assumes any legal liability or responsibility for any third party's use, or the results of such use, of any information, apparatus, product or process disclosed in this report, or represents that its use by such third party would not infringe privately owned rights. The views expressed in this paper are not necessarily those of the U.S. Government or the sponsoring agency. 


\title{
POST-HARVEST PROCESSING METHODS FOR REDUCTION OF SILICA AND ALKALI METALS IN WHEAT STRAW
}

\author{
David N. Thompson*, Peter G. Shaw, and Jeffrey A. Lacey \\ Biotechnology Department \\ Idaho National Engineering and Environmental Laboratory \\ P.O. Box 1625 \\ Idaho Falls, ID 83415-2203 \\ * Corresponding author.
}

\section{AUTHOR INFORMATION}

David N. Thompson, phone: (208) 526-3977, email: thomdn@inel.gov Peter G. Shaw, phone: (208) 526-5917, email: sgp@inel.gov

Jeffrey A. Lacey, phone: (208) 526-7010, email: 1aceja@inel.gov

FAX number for all authors: (208) 526-0828

Running title: Removal of minerals from wheat straw

$24^{\text {th }}$ Symposium on Biotechnology for Fuels and Chemicals

Poster \#1-30

May 2002 


\title{
Post-Harvest Processing Methods for Reduction of Silica and Alkali Metals in Wheat Straw
}

\author{
David N. Thompson*, Peter G. Shaw, and Jeffrey A. Lacey \\ Biotechnology Department, Idaho National Engineering and Environmental Laboratory \\ P.O. Box 1625, Idaho Falls, ID 83415-2203 \\ * Corresponding author.
}

\section{SUMMARY}

Silica and alkali metals in wheat straw limit its use for bioenergy and gasification. Slag deposits occur via the eutectic melting of $\mathrm{SiO}_{2}$ with $\mathrm{K}_{2} \mathrm{O}$, trapping chlorides at surfaces and causing corrosion. A minimum melting point of $950^{\circ} \mathrm{C}$ is desirable, corresponding to $\mathrm{SiO}_{2}: \mathrm{K}_{2} \mathrm{O}$ of about $3: 1$. Mild chemical treatments were used to reduce $\mathrm{Si}, \mathrm{K}$, and $\mathrm{Cl}$, while varying temperature, concentration, $\%$-solids, and time. Dilute acid was more effective at removing $\mathrm{K}$ and $\mathrm{Cl}$, while dilute alkali was more effective for Si. Reduction of minerals in this manner may prove economical for increasing utilization of the straw for combustion or gasification.

KEYWORDS: Bioenergy, combustion, gasification, fluidized bed, silica, potassium, chloride, slagging INTRODUCTION

Agricultural crop residues are a valuable renewable resource from which to produce biobased products. In 1999, American farmers harvested 53,909,000 acres of wheat (1). The straw from this acreage of wheat represents over 100 million tons annually. Currently, some of the straw is harvested (baled) for use as livestock bedding or low-grade animal feed. However, these low-value uses provide only a minimal return. Nationally, only about $3.2 \%$ of the economic return on wheat is from straw (1). Producers have long recognized the potential economic and environmental benefits in producing bioenergy and bioproducts from excess wheat straw residue. However, the silica and alkali metals in wheat straw limit its use for bioenergy and gasification.

Because of slagging, fluidized bed combustors and gasifiers cannot be operated above the ash fusion temperature of the feedstock, and boilers can only be operated well above or well below the ash fusion temperature (2). Wheat straw contains significant amounts of low-melting ash, which is comprised 
of mineral oxides including primarily $\mathrm{SiO}_{2}, \mathrm{~K}_{2} \mathrm{O}$, and $\mathrm{CaO}$, with smaller amounts of $\mathrm{SO}_{3}, \mathrm{MgO}, \mathrm{Na}_{2} \mathrm{O}$, $\mathrm{Fe}_{2} \mathrm{O}_{3}, \mathrm{Al}_{2} \mathrm{O}_{3}$, and $\mathrm{TiO}_{2}$ (3). This mineral ash deposits onto furnace or heat transfer surfaces in two ways. "Slagging" is deposition of molten or highly viscous ash, and occurs in the hottest regions of the combustor or gasifier. In contrast, "fouling" is deposition by condensation of vaporized ash, and occurs in the cooler regions. Vaporized $\mathrm{KCl}$ is then held in close contact with the metal surfaces of the combustor or gasifier, causing corrosion. Ash fusibility is an important factor in determining whether slagging or fouling will occur. $\mathrm{K}_{2} \mathrm{O}$ and other oxides form a eutectic mixture with $\mathrm{SiO}_{2}$, lowering the ash fusion temperature (4). $\mathrm{K}_{2} \mathrm{O}$ is of particular importance in the slagging of biomass ash due to its high concentration. For comparison, pure $\mathrm{SiO}_{2}$ melts at $1703{ }^{\circ} \mathrm{C}(5)$, while a 4:1 $\mathrm{SiO}_{2} / \mathrm{K}_{2} \mathrm{O}$ mixture by wt melts at about $1100{ }^{\circ} \mathrm{C}$, a $3: 1$ mixture melts at about $950{ }^{\circ} \mathrm{C}$, and a $2.3: 1$ mixture melts at about $850{ }^{\circ} \mathrm{C}$ (6) (i.e. lower $\mathrm{SiO}_{2} / \mathrm{K}_{2} \mathrm{O}$ ratios lead to lower ash fusion temperatures). While an efficient operating temperature is about $1100^{\circ} \mathrm{C}$, the preferred minimum is about $950{ }^{\circ} \mathrm{C}$ depending on the design (6). Thus, an effective treatment to remove minerals from straw reducing slagging and corrosion during combustion or gasification will: (1) Reduce total $\mathrm{SiO}_{2}$ content; (2) Increase $\mathrm{SiO}_{2} /$ Alkaline oxide ratios, particularly $\mathrm{SiO}_{2} / \mathrm{K}_{2} \mathrm{O}$; and (3) Increase the $\mathrm{SiO}_{2} / \mathrm{KCl}$ ratio.

The cellulose-rich vascular tissues of straw stems contain relatively higher amounts of organic material and fermentable carbohydrates for conversion to bioenergy, biofuels and chemicals. In contrast, the formerly physiologically active tissues, including the leaves, sheaths and awns, are heavily impregnated with silica in the epidermal layer, and these tissues also contain higher amounts of noncarbohydrate organic components (i.e., protein, lipids, pigments, pectin, organic acids) than the stems. For cost-efficient utilization of straw and other crop residues for bioenergy or gasification, the undesirable mineral components must be removed. However, the current paradigm for straw utilization includes the necessity to transport all the components of the straw to the point of use. There is no cost-efficient way to remove undesirable components from straw before transportation. This is expensive not only because of the low bulk density of straw, but also because it brings the less valuable components to the manufacturer's gate and creates economic and environmental liabilities. 
In this paper, we describe tests conducted at the Idaho National Engineering and Environmental Laboratory (INEEL) to further reduce silica and alkali mineral loads in the straw stem fraction to allow its use for bioenergy production and gasification in fluidized beds and boilers. The objectives of this study were: (1) Reduce $\mathrm{SiO}_{2}$ content to minimize total slag formation; (2) Reduce $\mathrm{K}_{2} \mathrm{O}$, increasing the ratio of $\mathrm{SiO}_{2}$ to alkaline oxides and increasing the temperature at which the slag forms; (3) Remove chlorides, minimizing the potential for corrosion due to the generation of $\mathrm{KCl}$ vapor at metal surfaces beneath slagging and fouling deposits; and (4) Perform these reductions in a manner that can be used economically in both distributed and centralized systems.

\section{METHODS}

Wheat Straw. Westbred 936 wheat straw, a hard red spring variety, was obtained from Grant 4-D Farms (Rupert, ID). All straw utilized in the laboratory studies was produced during the year 2000 cropping season. Twenty large bales of Westbred $936(1.2 \mathrm{~m} \times 2.4 \mathrm{~m}$ bales $(4 \mathrm{ft} \times 8 \mathrm{ft}))$ were collected and stored in a stack at the side of the field, using only the protected center bales for the studies. To better handle the straw for the laboratory studies, the large bales were rebaled as needed into smaller $0.61 \mathrm{~m} \times$ $1.2 \mathrm{~m}(2 \mathrm{ft} \times 4 \mathrm{ft})$ bales containing about $22.7 \mathrm{~kg}(50 \mathrm{lb})$ each, and stored in covered storage. The straw was rethreshed before use in the mineral removal studies as described by Hess et al. (7), to remove the high-silica plant components including the leaves, sheaths, fines, and nodes. Only the separated straw stems were used in the laboratory studies.

Chemical wash procedure. Five to twenty grams of air-dried whole chopped straw or mechanicallyseparated straw stems were weighed to the nearest $0.1 \mathrm{mg}$ into a tared $500-\mathrm{mL}$ wide-mouth polypropylene, Teflon, or polycarbonate bottle. Sufficient wash solution was weighed into the bottle to achieve the desired solids- $\%$ for the experiment (4-16 wt $\%$ ). Wash solutions included distilled (DI) water, $0.1-5.0 \mathrm{wt} \% \mathrm{H}_{2} \mathrm{SO}_{4}$, or $0.1-1.0 \mathrm{wt} \% \mathrm{NaOH}$. The bottles were shaken at a minimum of $150 \mathrm{rpm}$ for 0.5-24 hours at the desired temperature $\left(25,37\right.$ or $\left.50^{\circ} \mathrm{C}\right)$. The liquid was then poured off into tared Pyrex beakers. The straw stems were washed quickly with about $25 \mathrm{~mL}$ of distilled water, which was added to the collected liquid. Both the collected liquid fraction and the treated stems were then dried at $90-105^{\circ} \mathrm{C}$ 
for at least 2 days. The dried samples were removed from oven, cooled, and their weights recorded. The dried straw samples were then ground to 60 mesh in a Wiley mill and stored at room temperature for carbohydrate, lignin, ash, and mineral analyses.

\section{Analytical methods.}

Ashing. At least 1 gram of dry straw, ground to $60 \mathrm{mesh}$, was weighed to the nearest $0.1 \mathrm{mg}$ into a dry, tared ceramic crucible. The residue from the collected liquid fraction was also dried and weighed. Ashing was done in a muffle furnace at $550-650{ }^{\circ} \mathrm{C}$ for $18-24$ hours. On selected samples, a duplicate or spike such as $\mathrm{SiO}_{2}$ flour or potassium silicate was added to the straw before ashing to validate silica measurements. Ashing temperatures as high as $940{ }^{\circ} \mathrm{C}$ were used to determine weight loss as a function of temperature and composition changes from the volatilization of $\mathrm{KCl}$.

\section{Mineral analyses.}

Energy Dispersive Spectrometry. Mineral analyses were done by Energy Dispersive Spectrometry (EDS), modifying existing geological and metallurgical procedures (8). The spectra were measured at 10-20 KeV using a Phillips XL30ESEM Scanning Electron Microscope with a Princeton Gamma Tech Detector (Princeton, NJ). Compositions of minerals in the ash were determined for the elements Si, K, Ca, S, Mg, Mn, Ti, Fe, Al, P, Na, Cl, O. Except for some carbon that remains after the ashing and some losses of $\mathrm{KCl}$ these elements should account for $>95 \%$ of the ash. Ashed straw was placed in a thin film onto an aluminum disk using double-sided tape, taking care to transfer as much ash as possible onto the taped disk. The disks were then carbon-coated to prevent charging. Two or three separate $1.0 \mathrm{~mm}^{2}$ areas of each disk were scanned to verify homogeneity, depending on whether the measured Si values differed by more than one percent among measurements. Scanning was done for 5-10 minutes, with longer times used for samples containing very small distinguishable peaks.

EDS standards, prepared from reagent grade silicates, oxides, and chlorides, and ashed at the same temperatures used for the samples, were used to prepare calibration curves to correct the internal quantitative EDS values for matrix effects. In addition, Standard Reference Materials, including coal fly 
ash (SRM \#1633 and \#2690) and soil (SRM \#2710), both from the National Institute of Standards and Technology (Gaithersburg, MD), were also used to check the accuracy of the instrument and the quantification software. Finally some straw samples were analyzed by Inductively-Coupled Plasma (ICP) analysis (9) to validate the EDS results. Oxide compositions were calculated from the elements based on standard stoichiometric ratios.

Inductively-Coupled Plasma. Mineral analysis by ICP (9) was done to validate EDS results (>1 $\mathrm{wt} \% \mathrm{~K}$ and $\mathrm{Ca},<1 \mathrm{wt} \% \mathrm{P}, \mathrm{K}, \mathrm{S}, \mathrm{Mg}, \mathrm{Fe})$ and quantify trace elements $(<0.1 \mathrm{wt} \%)$, particularly the composition of straw micro-nutrients in the ash, such as $\mathrm{Cu}, \mathrm{Zn}, \mathrm{Mn}$ and B. Straw samples and standard reference material / calibration standards used for the EDS analyses were shipped to Western Labs (Parma, ID) for ICP analyses. Western Labs measured P, Ca, K, Cu, Zn, B, Fe, and Mn using standard methods (10).

Carbohydrate and lignin analysis. Carbohydrate and lignin compositions of untreated and treated straw samples were determined by quantitative saccharification using the method of Saeman et al. (11). Carbohydrate analyses were done by high performance liquid chromatography (HPLC) using a BioRad HPX-87P carbohydrate column, and lignin was calculated by weight difference as Klasson lignin with extractives and ash.

\section{RESULTS AND DICUSSION}

The organic and ash compositions of the untreated baled straw and untreated mechanically separated straw stem fraction are shown in Table 1. Mechanical separation reduced the total ash and $\mathrm{SiO}_{2}$ concentrations of the harvested fraction by $23 \%$ and $44 \%$, respectively, thereby reducing overall slagging potential (7). However, mechanical separation concentrated the alkali metals relative to $\mathrm{SiO}_{2}$, reducing the $\mathrm{SiO}_{2} / \mathrm{K}_{2} \mathrm{O}$ and $\mathrm{SiO}_{2} / \mathrm{KCl}$ ratios. Although reduction of total $\mathrm{SiO}_{2}$ is important for overall reduction of potential slag formation, in terms of modifying the eutectic properties and thereby raising the ash fusion temperature, removal of $\mathrm{SiO}_{2}$ is detrimental without also removing proportional amounts of $\mathrm{K}$, since it decreases the $\mathrm{SiO}_{2} / \mathrm{K}_{2} \mathrm{O}$ ratio in the ash.

Washing straw with aqueous liquids removed both organic and mineral matter. Most of the 
removal occurred in the first 4 hours of washing. The ratio of organic losses to inorganic losses were similar with all of the wash solutions; that is, no particular wash solution was more selective for dissolution of organic components or minerals. Rather, the minerals appeared to be released along with organic material, such that very short or very long washes released approximately the same ratio of organic and inorganic components of the straw.

Three wash solutions, including distilled (DI) water, dilute $\mathrm{H}_{2} \mathrm{SO}_{4}$, and dilute $\mathrm{NaOH}$, were used separately to remove minerals from separated stems and from chopped whole straw. A general comparison of the effects of these washes on $\mathrm{SiO}_{2} / \mathrm{K}_{2} \mathrm{O}, \mathrm{SiO}_{2} / \mathrm{KCl}$, and the loss of heating value, at 25,37 , and $50^{\circ} \mathrm{C}$ is shown in Figures $1-3$. Acid washing of straw removed most of the potassium by dissolution, and gave the highest $\mathrm{SiO}_{2} / \mathrm{K}_{2} \mathrm{O}$ ratios. Some acid washes removed sufficient potassium to raise the $\mathrm{SiO}_{2} / \mathrm{K}_{2} \mathrm{O}$ ratio above the desired minimum ratio of 3.0. The highest removal of $\mathrm{K}$ and $\mathrm{Cl}$ in straw stems occurred with an $0.2 \mathrm{wt} \%$ acid wash at $50^{\circ} \mathrm{C}$ (Figure 1). This acid wash increased the $\mathrm{SiO}_{2} / \mathrm{K}_{2} \mathrm{O}$ ratio from 0.9 to 3.2 , and increased the $\mathrm{SiO}_{2} / \mathrm{KCl}$ ratio from 0.5 to 71.3 (Figure 2), significantly reducing corrosion potential. For this calculation, it was assumed that all chlorine was present as $\mathrm{KCl}$. The concentration of $\mathrm{SiO}_{2}$ in the DI water- and acid-washed stems remained constant even though other mass was lost. Thus, both water and acid removed some $\mathrm{SiO}_{2}$ but its removal was offset by the removal of organic matter, and the concentration in the washed stems remained the same. Alkaline washing dissolved up to $20 \%$ of the $\mathrm{SiO}_{2}$ and slightly lowered the final $\mathrm{SiO}_{2}$ concentration in the straw. However, the $\mathrm{SiO}_{2} / \mathrm{K}_{2} \mathrm{O}$ ratio was lowered because a proportional amount of potassium was not removed.

The effect of wash solution and temperature on loss of heating value is shown in Figure 3. For these calculations, all components of the organic matter were assumed to be of equal heating value per unit weight. In general, higher wash temperatures resulted in greater loss of mass in acid washes, with smaller increases in the base and water washes. Increases in acid concentration increased the amount of mineral removed, but did so at the expense of BTU content since organic matter was also removed; about $80 \%$ of the mass removed in the acid washes was organic (not shown). These losses, amounting to 6- 
$11 \%$, indicate that there is a trade-off between the cost of the lost heating value and the benefits of reducing minerals through use of the treatment.

The effects of chemical washing of straw on the organic component mass balances are shown for selected experiments in Figures 4-7, while the $\mathrm{SiO}_{2} / \mathrm{K}_{2} \mathrm{O}, \mathrm{SiO}_{2} / \mathrm{KCl}$, and percentage of the ash represented by $\mathrm{SiO}_{2}, \mathrm{~K}_{2} \mathrm{O}$, and $\mathrm{KCl}$ are given in Table 2. Figure 4 shows a comparison of a $24 \mathrm{~h}, 15 \mathrm{wt} \%$-solids wash and a $4 \mathrm{~h}, 16 \mathrm{wt} \%$-solids wash of straw stems. Note that DI water is a slightly more aggressive solvent than tap water because it has been demineralized; thus, the DI water washes indicate the maximum removals possible using water. Equilibrium was reached by 4 hours in all washes. The effect of percentage solids (solids loading) in the DI water washes is also shown in Figure 4. Increasing the \%solids resulted in decreased removal of both organic matter and minerals. This occurred whether the straw remained immersed in the bulk liquid, or was only partly immersed (15\%-solids). This indicates that the process is solubility limited as long as the straw is submersed, and may become liquid-solid contact-limited at solids loadings as high as $15 \%$-solids.

It was also observed that the differences between mineral removal at low and elevated temperatures $\left(37\right.$ and $50^{\circ} \mathrm{C}$; not shown) was not as great at higher mass loadings, since solubility limits the amount of material that can be dissolved rather than the more aggressive solvent characteristics secured at the higher temperature. Washing with water removed $11.1 \%$ of the mass of straw in a $4 \%$ fully-submerged suspension, while only $6.8 \%$ mass was removed in a $15 \%$ partially-submerged suspension. The ash concentration of unwashed straw was reduced to $4.6 \%$ in the $4 \%$-solids water wash, but to only $6.7 \%$ in the $15 \%$-solids wash. A continuous wash that lowers the effective "loading" even further would overcome the solubility limitations and may result in higher mineral losses than experienced in these batch experiments. However, acidic or alkaline washing in a continuous process may present some difficulty in removing the residual wash fluid from the straw if residual $\mathrm{SO}_{4}$ or $\mathrm{Na}$ is not desirable. In the specific case of $\mathrm{Na}$, this would definitely not be desirable, since both $\mathrm{Na}$ and $\mathrm{K}$ contribute to the eutectic composition and lower the ash fusion temperature. The straw stems absorbed about 3.7 times their weight of water, and chopped whole straw absorbed 4.2 times its weight. Thus, 
residual $\mathrm{SO}_{4}$ or $\mathrm{Na}$ might be difficult to remove efficiently without significant further water washes.

Mass balances for washing of straw stems at $25^{\circ} \mathrm{C}$ with dilute acid at various acid concentrations are shown in Figure 5, while Figure 6 shows the same for whole straw at $50{ }^{\circ} \mathrm{C}$. Higher acid concentrations were required to reach the same $\mathrm{SiO}_{2} / \mathrm{K}_{2} \mathrm{O}$ ratios for whole straw as reached for stems at $50{ }^{\circ} \mathrm{C}$ (not shown). Still, $\mathrm{SiO}_{2} / \mathrm{K}_{2} \mathrm{O}$ ratios obtained with whole straw approached the minimum acceptable level of 3.0. However, the whole straw contains larger amounts of silica (separated from the stem fraction in the selective harvest), and therefore greater slagging potential. Both the mineral and organic content removed increased with higher acid concentrations. The highest $\mathrm{K}$ removal without excessive loss of organic matter was achieved at $50{ }^{\circ} \mathrm{C}$ with $0.2 \mathrm{wt} \% \mathrm{H}_{2} \mathrm{SO}_{4}$ in a $4 \%$ straw suspension (see Figure 2 above). The $\mathrm{SiO}_{2} / \mathrm{K}_{2} \mathrm{O}$ ratio achieved in this run was approached with whole straw $\left(\mathrm{SiO}_{2} / \mathrm{K}_{2} \mathrm{O}\right.$ of 2.8$)$ at $10 \%$ solids, which was not achievable with stems alone at $10 \%$-solids. This may be because the whole straw starts at a higher $\mathrm{SiO}_{2} / \mathrm{K}_{2} \mathrm{O}$ ratio than stems alone, since the mechanical stem separation concentrated the alkali metals relative to the silica in the stems. In any event, lowering the solids content would probably produce washed straw with a $\mathrm{SiO}_{2} / \mathrm{K}_{2} \mathrm{O}$ ratio above the desired minimum of 3.0.

Generally cellulose and hemicellulose concentrations were not significantly affected by dilute acid washes with acid concentrations up to $0.4 \%$. However, Figure 5 shows significant loss of hemicellulose in a $1 \% \mathrm{H}_{2} \mathrm{SO}_{4}$ wash. A $5 \% \mathrm{H}_{2} \mathrm{SO}_{4}$ wash (not shown) resulted in complete loss of both cellulose and hemicellulose. In these experiments, the mass balances indicated a shift from cellulose and hemicellulose to an acid insoluble fraction, generally referred to as Klasson lignin in the quantitative saccharification technique (11). It is believed that significant $\mathrm{H}_{2} \mathrm{SO}_{4}$ remained within the straw lignocellulosic matrix during the $105{ }^{\circ} \mathrm{C}$ drying step. Thus as water was removed, the $\mathrm{H}_{2} \mathrm{SO}_{4}$ was concentrated, eventually reacting with the polysaccharides at the elevated temperature and converting them to acid-insoluble organic matter. Assuming that the acid-insoluble organic was still combustible, the total BTU content may not be significantly affected, since the decomposition products were not lost, but converted to the "lignin" category in Figure 5. Hence, it is clear that acid concentrations of $1 \mathrm{wt} \%$ 
and higher should not be used if recovery of intact carbohydrates is desired.

The effect of size reduction is demonstrated in Figure 6. As this chopped $(3 / 4$ inch and smaller fragments) straw had not been physically separated, the initial mineral (ash) content was higher at 11.2\%. Size reduction increased the contact surface area and the mass that could be fully immersed. Ash removal upon washing was not improved, indicating solubility constraints were of greater importance than surface contact. The chopped whole straw was washed in water and various dilute $\mathrm{H}_{2} \mathrm{SO}_{4}$ solutions at 6.7 and 10 $\mathrm{wt} \%$ solids. The mass lost after washing was $14.1 \%$ for the chopped straw at $6.7 \%$ loading. This was comparable to previous tests where $15.3 \%$ loss for straw stems at $4.5 \%$ loading was observed. The inorganic mineral concentration was reduced from 11.2 to $6.4 \%$ in the chopped whole straw, and from 8.7 to $4.2 \%$ in the unchopped straw stems.

It seems clear from the data presented in this paper that acid is preferred as a wash solution for removal of alkali minerals from straw for use in fluidized bed combustors or gasifiers or in boilers. Future work includes testing acid-washed whole straw and physically separated straw stems in a fluidized bed combustor to determine the combustion and slagging properties of the washed straw. In addition, we would like to test the effect of adding $\mathrm{CaO}$ or $\mathrm{MgO}$ after washing, since $\mathrm{CaO}$ and $\mathrm{MgO}$ can modify the eutectic composition and thereby increase the ash fusion temperature further (2). While $\mathrm{CaO}$ or $\mathrm{MgO}$ could be directly added to the straw without washing to achieve an increase in ash fusion temperature, washing the straw removes large amounts of potassium and thus less $\mathrm{CaO}$ and $\mathrm{MgO}$ would be required to significantly alter the ash fusion temperature. Data from these tests, and estimation of eutectic compositions and ash fusion temperatures, will help in the application of these separations to fluidized bed combustion and gasification of biomass and combustion in boilers. The acid-washed straw will also be tested for ease of drying and densification as part of a distributed bioenergy system.

\section{CONCLUSIONS}

Mechanical separation of straw reduced ash and $\mathrm{SiO}_{2}$ concentration in straw by removing leaves and sheaths and leaving primarily stems. However this concentrated $\mathrm{K}$ relative to $\mathrm{SiO}_{2}$, reducing the $\mathrm{SiO}_{2} / \mathrm{K}_{2} \mathrm{O}$ and $\mathrm{SiO}_{2} / \mathrm{KCl}$ ratios, which are important measures of slagging and corrosion potential. 
Chemical washes removed much of the soluble $\mathrm{K}$ and up to $11 \%$ organic matter. Dilute acid removed both $\mathrm{K}$ and $\mathrm{Cl}$ while dilute base removed limited amounts of $\mathrm{SiO}_{2}$. Elevated temperatures increased both mineral removal rate, and with sufficient bulk liquid, the amount removed. The highest $\mathrm{SiO}_{2} / \mathrm{K}_{2} \mathrm{O}$ ratio achieved was 3.2, using a $4 \mathrm{~h}$ wash in $0.2 \mathrm{wt} \% \mathrm{H}_{2} \mathrm{SO}_{4}$ at $50^{\circ} \mathrm{C}$, using a $4 \%$ straw stem suspension. Increasing the solids loading minimized loss of organics, but also reduced mineral removal. Washing improved $\mathrm{SiO}_{2} / \mathrm{K}_{2} \mathrm{O}$ and $\mathrm{SiO}_{2} / \mathrm{KCl}$ ratios for both physically separated straw stems and whole straw.

\section{ACKNOWLEDGEMENTS}

The authors thank the University of Idaho, Aberdeen Research and Extension Center, for use of their plot harvesting equipment for the mechanical separations. We also thank Dr. Judi Steciak at the University of Idaho and Dr. Robert Carrington at the INEEL for useful discussions on biomass slagging and combustion. Finally, we thank Tracy Houghton at the INEEL, who performed the quantitative saccharification analyses. This work is supported by the U.S. Department of Energy through the INEEL Laboratory Directed Research and Development Program under DOE Idaho Operations Office Contract DE-AC07-99ID13727.

\section{REFERENCES}

1. USDA NASS. (2001), United States Department of Agriculture, National Agricultural Statistics Service. http://www.usda.gov/nass/.

2. Stultz, S. C. and Kitto, J.B. (eds.). (1992), Steam: Its Generation and Use, $40^{\text {th }}$ Edition, Babcock \& Wilcox Co., Barberton, OH.

3. Jenkins, B.M., Baxter, L.L., Miles, Jr., T.R., and Miles, T.R. (1999), Fuel, 78, 17-46.

4. Seggiani, M. (1999), Fuel, 78, 1121-1125.

5. Weast, R.C., Astle, M.J., and Beyer, W.H. (eds). (1983), CRC Handbook of Chemistry and Physics, $64^{\text {th }}$ Edition, CRC Press, Inc., Boca Raton, FL, p. B-135.

6. Steciak, J. (2001), Personal communication (unpublished data), Department of Mechanical Engineering, The University of Idaho, Boise, ID. 
7. Hess, J.R., Thompson, D.N., Hoskinson, R.L., Shaw, P.G., and Grant, D.R. (2003), Appl. Biochem. Biotechnol., THIS VOLUME, PAGES.

8. ASTM E1508. (1998), Standard guide to Quantitative Analysis by Energy Dispersive Spectroscopy, American Society for Testing and Materials, Philadelphia, PA.

9. Method 305. (1985), Metals by ICP, Standard Method for The Examination of Water and Waste Water, $16^{\text {th }}$ Edition, APHA, AWWWA and WPCF.

10. (1994), Plant, Soil, and Water Reference Methods for the Western Region, Far West Fertilizer and Agrichemical Association, May 1994.

11. Saeman, J.F., Bubl, J.L. and Harris, E.E. (1945), Ind. Eng. Chem., 17(1), 35-37.

\section{FIGURE LEGENDS}

Figure 1: $\mathrm{SiO}_{2} / \mathrm{K}_{2} \mathrm{O}$ ratio after acid, alkali, or water washing of straw stems at various temperatures.

Figure 2: $\mathrm{SiO}_{2} / \mathrm{KCl}$ ratio after acid, alkali, or water washing of straw stems at various temperatures.

Figure 3: Loss of heating value as a function of acid, alkali, and water washing of straw stems at various temperatures.

Figure 4: Mass balances for unwashed straw stems and for washed straw stems using DI water at $25^{\circ} \mathrm{C}$ for 4 or $24 \mathrm{~h}$, with increasing $\%$-solids.

Figure 5: Mass balances for unwashed straw stems and for washed straw stems using dilute $\mathrm{H}_{2} \mathrm{SO}_{4}$ at $25^{\circ} \mathrm{C}$ for $4 \mathrm{~h}$, at $4 \%$-solids, with increasing acid concentration.

Figure 6: Mass balances for unwashed whole chopped straw and for washing of whole chopped straw using dilute $\mathrm{H}_{2} \mathrm{SO}_{4}$ at $50^{\circ} \mathrm{C}$ for $24 \mathrm{~h}$, at $10 \%$-solids, with increasing acid concentration. 


\section{TABLES}

Table 1: Organic and Inorganic Composition of whole Westbred 936 straw and the mechanicallyseparated straw stem fraction.

\begin{tabular}{|c|c|c|}
\hline \multirow[b]{2}{*}{ Component } & \multicolumn{2}{|c|}{$\mathrm{Wt} \%$ of Component $\mathrm{a}^{\mathrm{a}}$ in } \\
\hline & $\begin{array}{l}\text { Westbred } 936 \\
\text { Whole straw }\end{array}$ & $\begin{array}{c}\text { Westbred } 936 \\
\text { Stems only }\end{array}$ \\
\hline Glucan & 32.1 & 37.2 \\
\hline Xylan & 19.3 & 19.4 \\
\hline Galactan & 1.0 & 0.9 \\
\hline Mannan & 4.5 & 3.0 \\
\hline Arabinan & 2.1 & 1.6 \\
\hline Lignin with Extractives & 20.3 & 18.9 \\
\hline Other $^{c}$ & 9.5 & 10.3 \\
\hline $\mathrm{Ash}^{\mathrm{b}} \mathrm{wt} \%$ & 11.2 & 8.7 \\
\hline $\mathrm{SiO}_{2}$ & 2.6 & 1.3 \\
\hline $\mathrm{K}_{2} \mathrm{O}^{\mathrm{d}}$ & 1.7 & 1.2 \\
\hline $\mathrm{KCl}^{\mathrm{d}}$ & 5.2 & 5.2 \\
\hline $\mathrm{CaO}$ & 0.6 & 0.2 \\
\hline $\mathrm{SO}_{3}$ & 0.4 & 0.3 \\
\hline $\mathrm{MgO}$ & 0.3 & 0.2 \\
\hline $\mathrm{P}_{2} \mathrm{O}_{5}$ & 0.2 & 0.1 \\
\hline $\mathrm{FeO}$ & 0.04 & 0.05 \\
\hline $\mathrm{Na}_{2} \mathrm{O}$ & 0.06 & 0.04 \\
\hline $\mathrm{MnO}_{2}$ & 0.005 & 0.003 \\
\hline $\mathrm{CuO}$ & 0.0005 & 0.0005 \\
\hline $\mathrm{B}_{2} \mathrm{O}_{3}$ & 0.005 & 0.005 \\
\hline $\mathrm{Al}_{2} \mathrm{O}_{3}$ & 0.0002 & $<0.005$ \\
\hline $\mathrm{TiO}_{2}$ & $<0.005$ & 0.0001 \\
\hline $\mathrm{ZnO}$ & 0.0007 & 0.004 \\
\hline SUM & 100 & 100 \\
\hline
\end{tabular}

a. Based on $100 \%$ dry weight of material

b. Oxide contents estimated by mass balance from elemental composition as determined by EDS

c. Other organics are attributed to uronic acid, protein, etc. contents and to recovery errors in carbohydrate analysis technique.

d. Potassium assumed to first combine with available chlorine then apportioned as oxide 
Table 2: $\mathrm{SiO}_{2} / \mathrm{K}_{2} \mathrm{O}, \mathrm{SiO}_{2} / \mathrm{KCl}$, and percentage of the ash represented by $\mathrm{SiO}_{2}, \mathrm{~K}_{2} \mathrm{O}$, and $\mathrm{KCl}$ for the washes shown in Figures 4-6.

\begin{tabular}{|c|c|c|c|}
\hline Condition & $\mathrm{SiO}_{2} / \mathrm{K}_{2} \mathrm{O}$ & $\mathrm{SiO}_{2} / \mathrm{KCl}$ & $\mathrm{wt} \% \mathrm{SiO}_{2}, \mathrm{~K}_{2} \mathrm{O}, \& \mathrm{KCl}$ \\
\hline \multicolumn{4}{|c|}{ 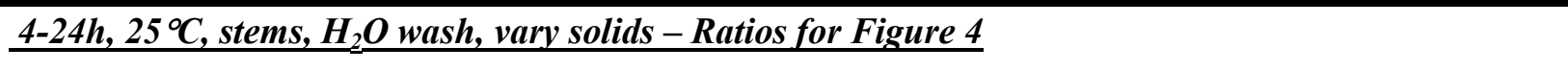 } \\
\hline Unwashed stems & 0.9 & 0.3 & 92.9 \\
\hline $2 \mathrm{wt} \%$-solids, $4 \mathrm{~h}$ wash & 1.3 & 32.8 & 88.0 \\
\hline $4 \mathrm{wt} \%$-solids, $4 \mathrm{~h}$ wash & 1.2 & 4.7 & 78.5 \\
\hline $15 \mathrm{wt} \%$-solids, $24 \mathrm{~h}$ wash & 2.4 & 3.3 & 84.2 \\
\hline $16 \mathrm{wt} \%$-solids, $4 \mathrm{~h}$ wash & 2.4 & 3.3 & 84.2 \\
\hline \multicolumn{4}{|c|}{$4 \mathrm{~h}, 4 \%$ solids, $25^{\circ} \mathrm{C}$, stems, acid wash - Ratios for Figure 5} \\
\hline Unwashed stems & 0.9 & 0.3 & 92.9 \\
\hline $0 \mathrm{wt} \% \mathrm{H}_{2} \mathrm{SO}_{4}$ & 1.2 & 11.7 & 85.7 \\
\hline $0.2 \mathrm{wt} \% \mathrm{H}_{2} \mathrm{SO}_{4}$ & 1.3 & $>75^{\mathrm{a}}$ & 83.9 \\
\hline $0.4 \mathrm{wt} \% \mathrm{H}_{2} \mathrm{SO}_{4}$ & 2.4 & $>75$ & 93.5 \\
\hline $1.0 \mathrm{wt} \% \mathrm{H}_{2} \mathrm{SO}_{4}$ & 2.8 & $>75$ & 90.6 \\
\hline \multicolumn{4}{|c|}{$24 h, 10 \%$ solids, $50^{\circ} \mathrm{C}$, whole straw, acid-Ratios for Figure 6} \\
\hline Unwashed whole straw & 1.3 & 0.5 & 96.4 \\
\hline $0 \mathrm{wt} \% \mathrm{H}_{2} \mathrm{SO}_{4}$ & 1.3 & 35.6 & 59.0 \\
\hline $0.2 \mathrm{wt} \% \mathrm{H}_{2} \mathrm{SO}_{4}$ & 2.3 & 13.2 & 63.0 \\
\hline $0.4 \mathrm{wt} \% \mathrm{H}_{2} \mathrm{SO}_{4}$ & 2.6 & 5.6 & 86.1 \\
\hline $1.0 \mathrm{wt} \% \mathrm{H}_{2} \mathrm{SO}_{4}$ & $\mathrm{nd}^{\mathrm{b}}$ & nd & nd \\
\hline
\end{tabular}

a $\mathrm{Cl}$ was not detected by EDS in this sample, so the approximate $\mathrm{Cl}$ detection limit was used to calculate the minimum possible $\mathrm{SiO}_{2} / \mathrm{KCl}$ ratio.

$\mathrm{b}$ nd $=$ not determined 


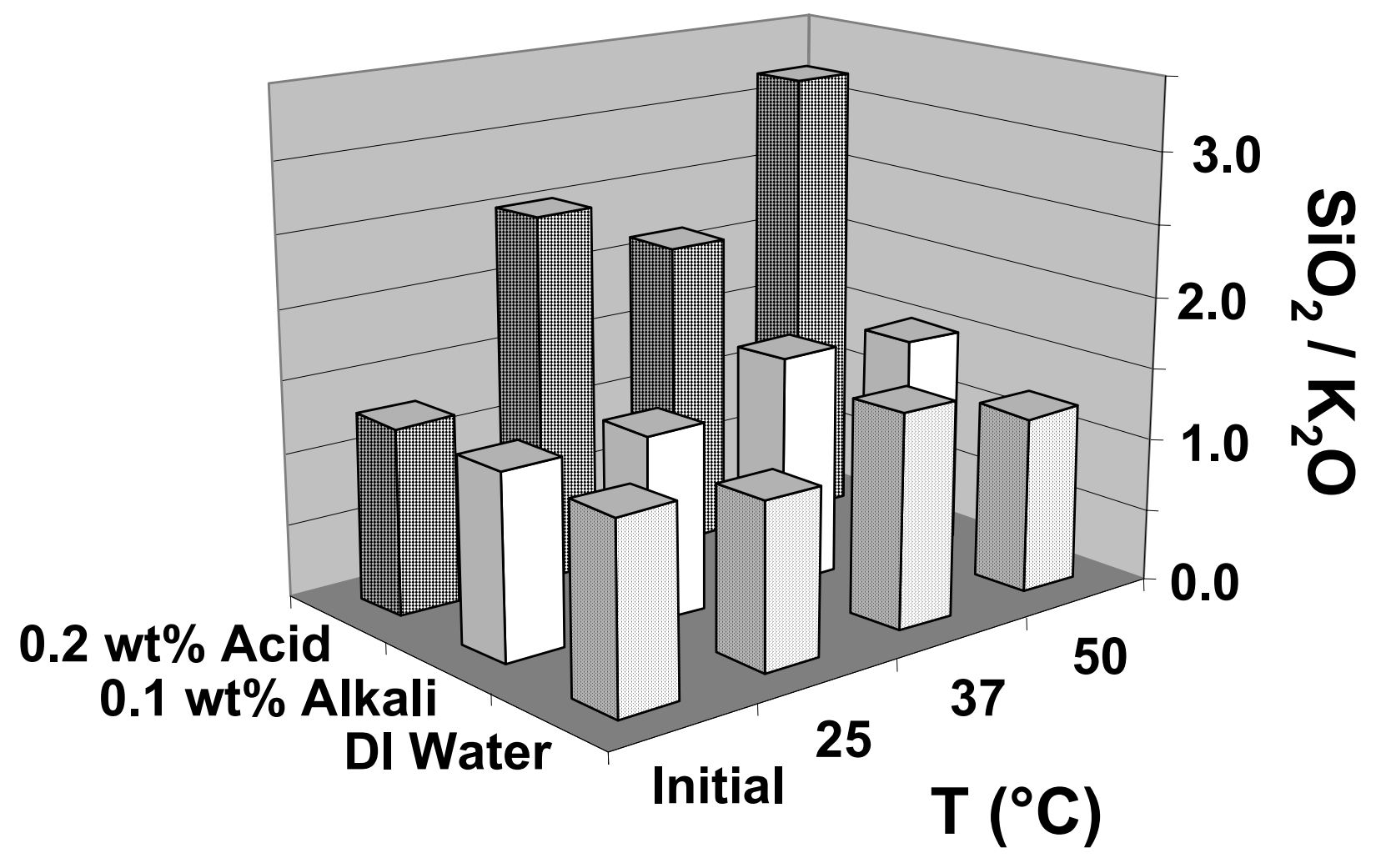

FIGURE 1 - Thompson, Shaw, and Lacey 


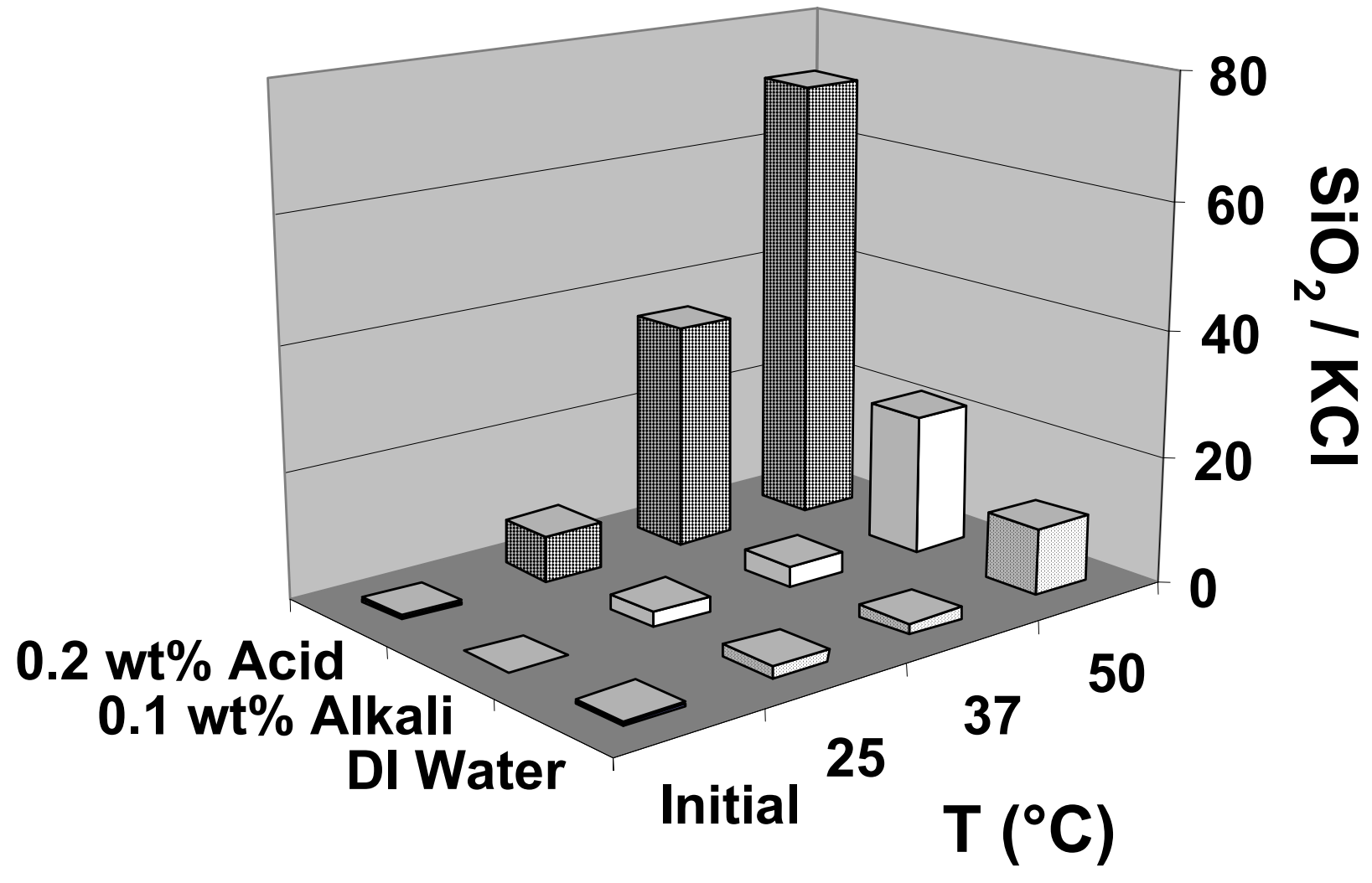

FIGURE 2 - Thompson, Shaw, and Lacey 


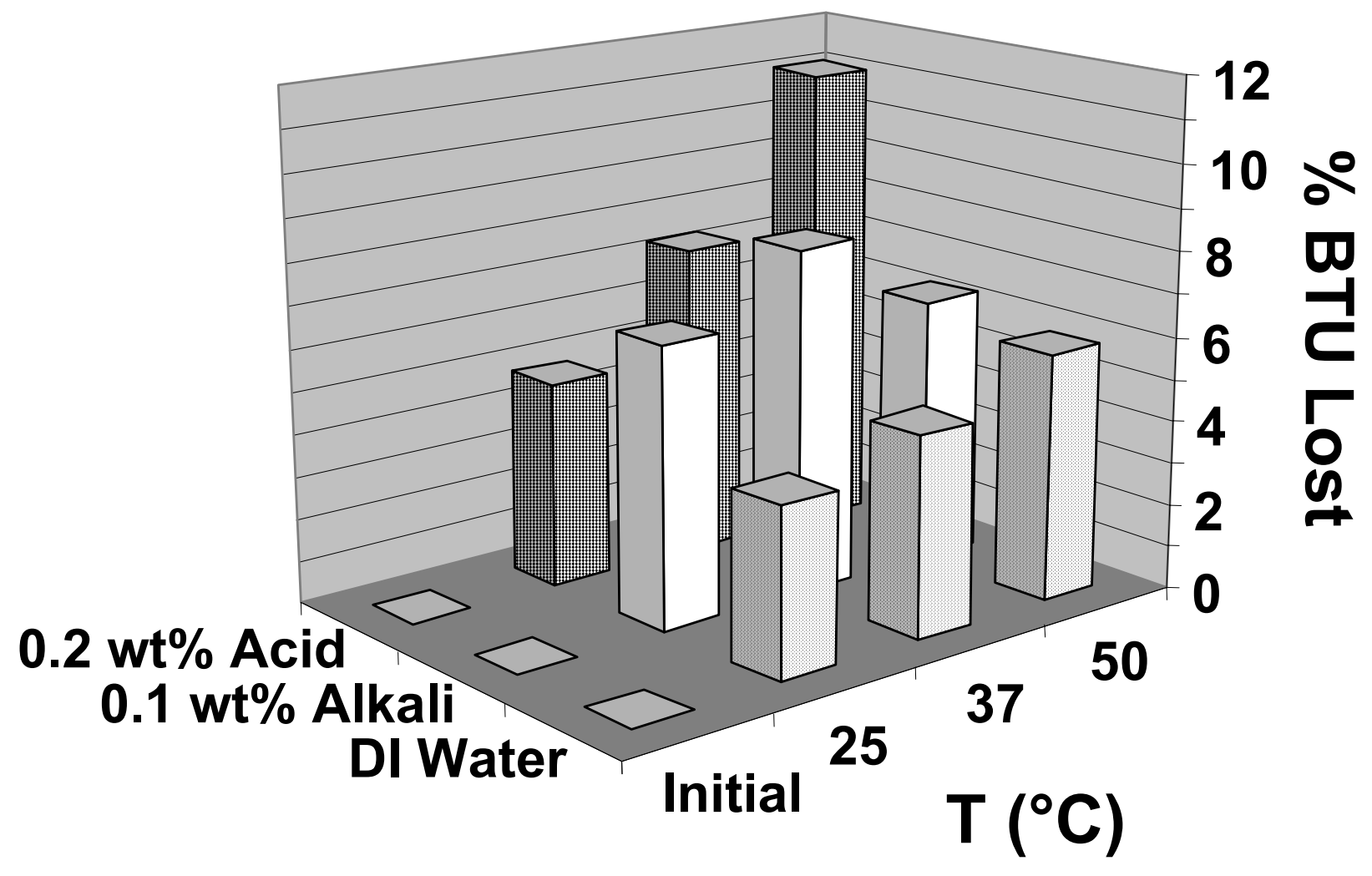

FIGURE 3 - Thompson, Shaw, and Lacey 


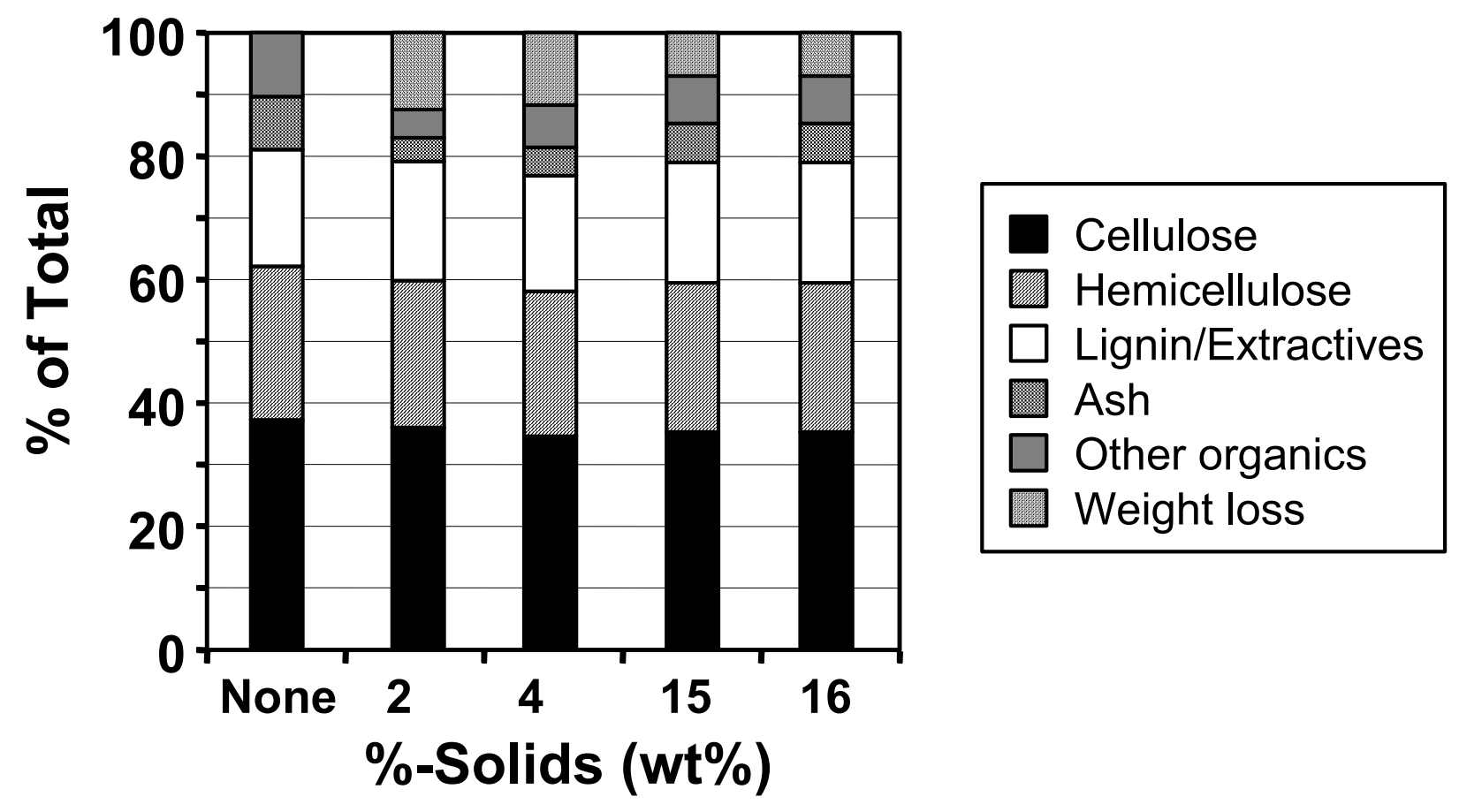

FIGURE 4 - Thompson, Shaw, and Lacey 


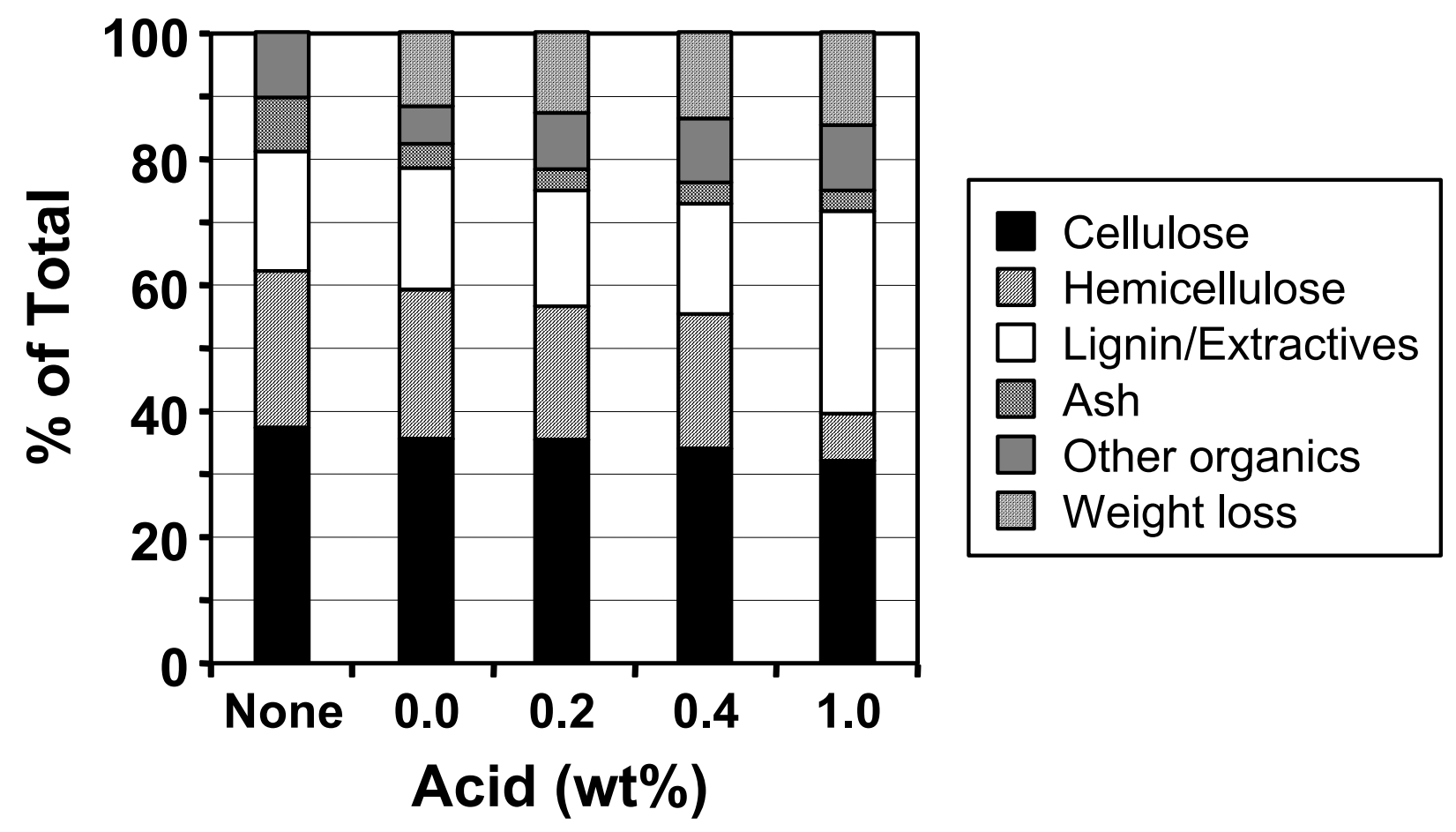

FIGURE 5 - Thompson, Shaw, and Lacey 


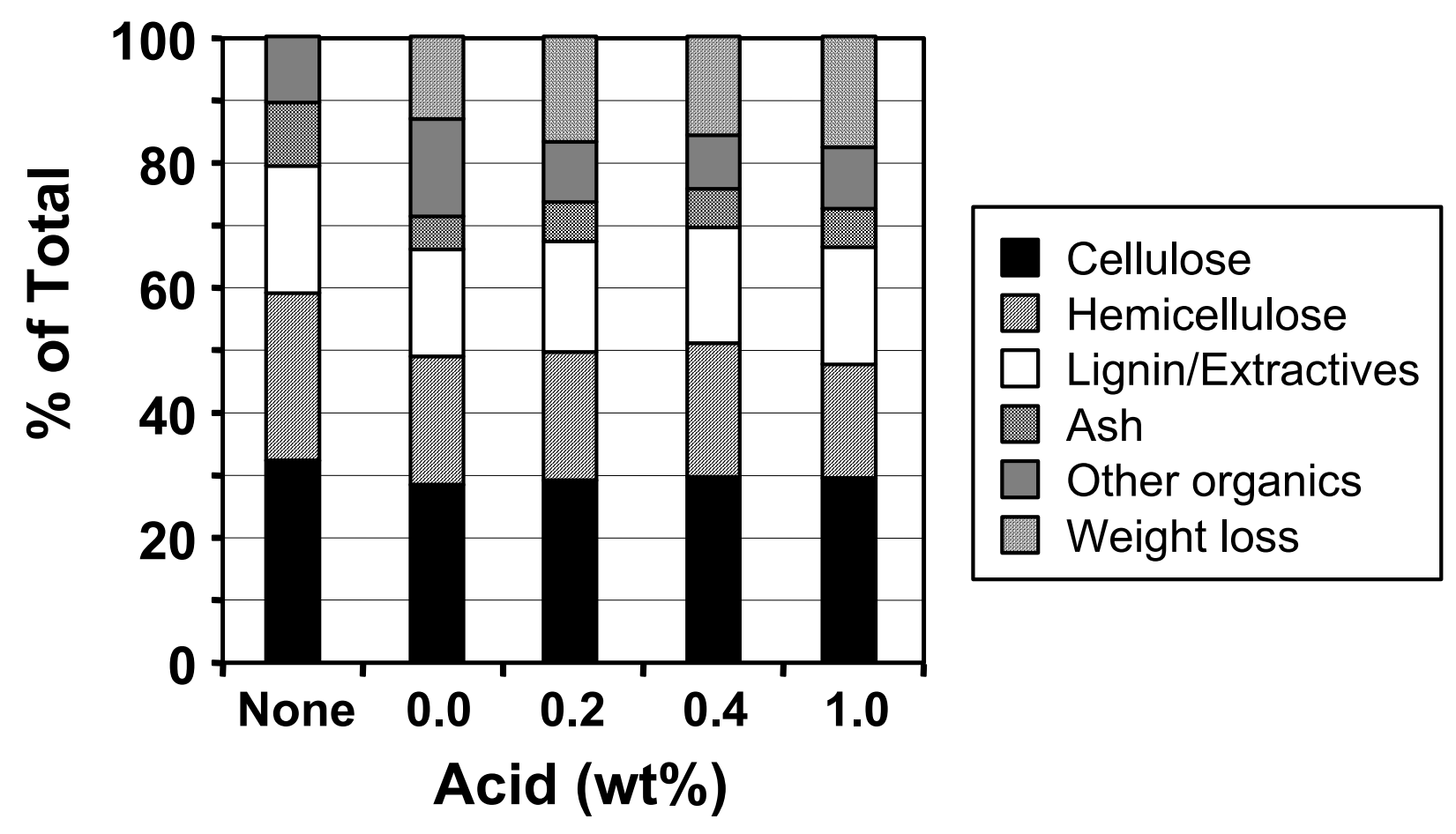

FIGURE 6 - Thompson, Shaw, and Lacey 